J. Perinat. Med. $12(1984) 127$

\title{
Maternal serum alpha-fetoprotein levels in low birth weight singleton pregnancies
}

\author{
C. M. Buckland, H. Thom, A.G. M. Campbell
}

Department of Child Health, University of Aberdeen, Great Britain

\section{Introduction}

Problems in the newborn period can sometimes be predicted by biochemical measurements in late pregnancy but there is, as yet, no definitive prenatal indicator of poor fetal growth. Although modern intensive care has improved the prognosis for light weight infants, management still presents problems especially when such births are unexpected.

At present, measurement of maternal serum $\alpha$ fetoprotein (MSAFP) between 16 and 20 weeks gestation is done primarily as a screening procedure for fetal neural tube defects (NTD). However, initial studies on the outcomes of pregnancies where high MSAFP values were found in the absence of fetal NTD suggested that these pregnancies were associated with low birth weight babies [1,7]. Since there is no evidence that MSAFP measurement at any time other than in the second trimester might predict low birth weight infants more efficiently $[2,8]$, it would be convenient if the routine MSAFP test were clinically useful in this respect. SMITH [5] has suggested that high MSAFP predicts prematurity whereas PURDIE et al. [4] concluded that growth retardation rather than prematurity was indicated. We have examined MSAFP levels in pregnancies resulting in low birth weight infants to assess their relationship in our population. Women with premature delivery and those with light for gestational age infants were analysed separately to find

\section{Curriculum vitae}

CATRIONA BUCKLAND was born in 1961 and studied statistics at Aberdeen University, graduating with Honours in 1982. As a temporary Research Assistant in the University Department of Child Health, she analysed accumulated data concerning the outcome of maternal serum AFP screening for fetal abnormality in the Grampian Region of Scotland. She is now a programmer/ analyst in Grampian Health Board's computing centre.

whether raised MSAFP was associated with one or both of these groups. Pregnancies ending in spontaneous abortion or stillbirth were also studied.

\section{Patients and methods}

Three hundred and eighty-nine pregnancies screened for NTD in the period January 1980 to December 1981 and resulting in a liveborn singleton weighing $2.5 \mathrm{~kg}$ or less were included. The variables recorded for each patient were birth weight, sex and gestation at birth, and MSAFP value expressed as a multiple of the median (MOM) value according to gestation for uncomplicated pregnancies with normal outcome at term. Pregnancies which were screened over the same period and ended in spon. 
taneous abortion or stillbirth were analysed separately. The MSAFP value was described as raised if it equalled or was greater than two multiples of the median value ( $\geq 2 \mathrm{MOM}$ ) for normal outcome in singleton pregnancies, otherwise it was classified as normal. However, for pregnancies screened in the Grampian Region of Scotland centered in Aberdeen, a MSAFP value of $2 \mathrm{MOM}$ is at the $95 \%$ centile of the normal range so that $5 \%$ of normal outcome pregnancies will have MSAFP at or above this level. Using this information, a statistical comparison was made with the proportion of raised MSAFP levels in the samples examined, (using a normal approximation to the binomial test for comparing proportions) to investigate whether the distribution of MSAFP levels differed from the general population.

Not all pregñancies resulting in low birth weight infants were screened for NTD. However, distributions of gestation, weight and sex, and whether or not the infant was light for gestational age were similar in screened and unscreened groups. Thus the screened group used in the following analysis may be assumed to be a representative sample of all low birth weight pregnancies. MSAFP was measured by double-antibody radioimmunoassay.

\section{Results}

There was no significant difference between the numbers of male and female infants. Table I shows the distribution of MSAFP levels according to birth weight. Overall there were $33(8.5 \%)$ women with raised MSAFP levels ( $\geq 2$ MOM) giving fairly strong evidence of an increased chance that women with low birth-weight babies had raised MSAFP values $(p<0.005)$. For birth-weights under $2.0 \mathrm{~kg}$ there appears to be an even greater risk: $11.7 \%$ of women had a raised MSAFP level $(p<0.001)$. The same may be true for those under $1.5 \mathrm{~kg}$ and under $1.0 \mathrm{~kg}$ but the sample size in these two groups is insufficient for firm conclusions to be drawn. However, there is evidence to suggest such an association (pooling MSAFP into normal/raised groups, and pooling weights $<1.5 \mathrm{~kg}, \mathrm{X}^{2}$ test $\mathrm{p}<0.02$ ).

Table II shows the distribution of MSAFP according to gestational age at delivery. There is weak evidence of an association between MSAFP and gestation ( $\mathrm{X}^{2}$ test, pooling AFP groups above 2 MOM, $p<0.09$ ). Although there may be an increased chance of raised MSAFP levels amongst patients delivering before 33 weeks of gestation ( $p<0.02)$, there is very little evidence of an association between raised MSAFP and prematurity as a whole (i.e. gestation under 37 weeks). However, for low birth weight infants born after 37 weeks of gestation, there is strong evidence of an increased chance of raised MSAFP levels; in this sample $9.8 \%$ of patients who were delivered after 37 weeks had raised MSAFP values ( $p<0.005)$.

These results suggested that raised MSAFP levels might indicate intra-uterine growth retardation (IUGR), i.e. light for gestational age infants. To clarify the situation, birthweights were then compared with standard birthweight centiles [6] according to gestation, sex and parity. An infant was classified as light-for-dates if its birthweight lay below the appropriate 10th centile, otherwise it was classified as appropriate-for-dates. Sixty-four

Tab. I. Maternal serum AFP and infant birthweight

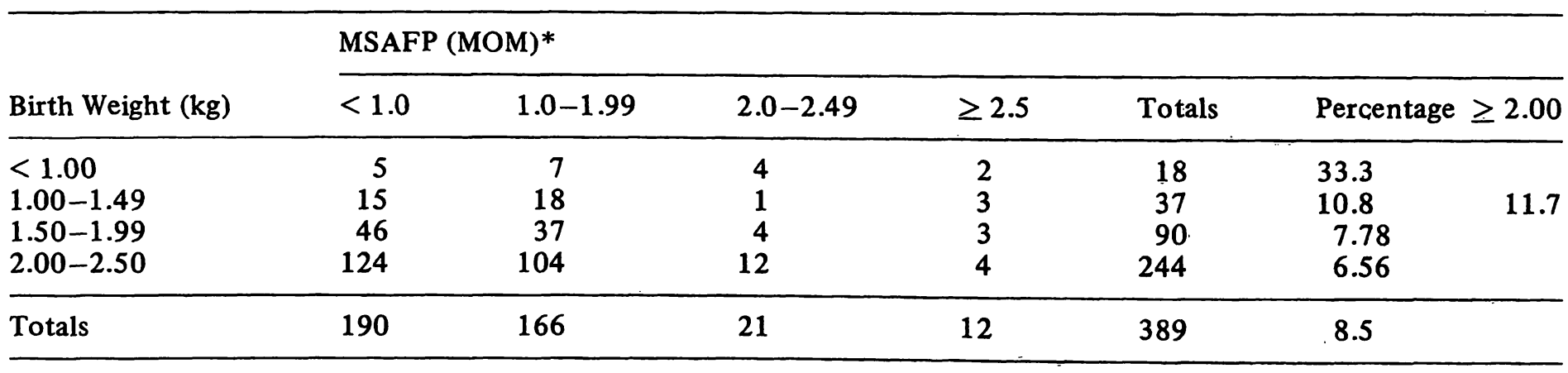

* expressed as multiples of the median values for normal outcome pregnancies at term. 
Tab. II. Maternal serum AFP and gestation at delivery

\begin{tabular}{|c|c|c|c|c|c|c|c|}
\hline \multirow[b]{2}{*}{ Gestation (weeks) } & \multicolumn{7}{|c|}{ MSAFP (MOM) } \\
\hline & $<1.0$ & $1.0-1.99$ & $1.0-2.49$ & $\geq 2.5$ & Total & Percentage & $\geq 2.00$ \\
\hline $\begin{array}{l}\leq 32 \\
33-36 \\
\geq 37\end{array}$ & $\begin{array}{l}33 \\
71 \\
86\end{array}$ & $\begin{array}{l}39 \\
66 \\
61\end{array}$ & $\begin{array}{r}5 \\
5 \\
11\end{array}$ & $\begin{array}{l}4 \\
3 \\
5\end{array}$ & $\begin{array}{r}81 \\
145 \\
163\end{array}$ & $\begin{array}{c}11.1 \\
5.52 \\
9.82\end{array}$ & 7.52 \\
\hline Total & 190 & 166 & 21 & 12 & 389 & 8.48 & \\
\hline
\end{tabular}

patients were not classifiable as they delivered before 32 weeks of gestation, outside the range of the available centiles.

Table III shows the results of this analysis. In the light-for-dates group, 19 out of 203 (9.4\%) had raised MSAFP levels, whereas in the appropriatefor-dates group, only six out of $122(4.9 \%)$ had raised MSAFP levels, comparable with the general population. Thus there was strong evidence of an increased chance of raised MSAFP in the lightfor-dates group $(\mathrm{p}<0.005)$.

\subsection{Spontaneous Abortions}

Fifty-five pregnancies ended in spontaneous abortion after 16 weeks where MSAFP levels had been measured prior to the abortion. Of these, eight women had raised MSAFP (14.5\%). This is strong evidence $(p<0.002)$ that raised MSAFP occurs more frequently in pregnancies ending in spontaneous abortion than in the general population.

\subsection{Stillbirths}

Sixty-one pregnancies ended with a stillborn infant. Five $(8.2 \%)$ women had raised MSAFP levels and there is little evidence to suggest that raised MSAFP in the second trimester has any association with subsequent stillbirth.

\section{Discussion}

These results are consistent with earlier studies, in that there appears to be an increased chance of raised MSAFP values in mothers who have infants of low birth weight. In our sample, $8.5 \%$ of these patients had raised MSAFP levels at 16-21 weeks of gestation, compared with $13.4 \%$ at $16-20$ weeks reported by SMITH [5].

From the above analysis, high MSAFP in singleton pregnancies without fetal defect would seem to be a predictor of light-for-dates infants, and possibly also extreme prematurity. However, the apparent association between very premature infants, born at 32 weeks of gestation or less, and high MSAFP, may be due to bias: if gestation is under-estimated, this will lead to an apparently high MSAFP level, and an apparently early delivery.

The association between IUGR and high MSAFP is of interest, but is unlikely to be of much practical

Tab. III. Maternal serum AFP of light and appropriate for gestational age babies

\begin{tabular}{llccc}
\hline & \multicolumn{2}{l}{ Light-for-dates } & \multicolumn{2}{l}{ Appropriate-for-dates } \\
\cline { 2 - 5 } Gestation (weeks) & MSAFP < 2 MOM & MSAFP > 2 MOM & MSAFP < 2 MOM & MSAFP > 2 MOM \\
\hline $32-34$ & 15 & 2 & 58 & 3 \\
$35-36$ & 33 & 1 & 47 & 3 \\
37 & 30 & 4 & 11 & 0 \\
$\geq 38$ & 106 & 12 & - & - \\
\hline Total & 184 & 19 & 116 & 6 \\
\hline
\end{tabular}


use, unless the predictive ability of MSAFP could be enhanced by combination with other tests. The MSAFP test identifies only a small proportion of pregnancies with IUGR (9.4\%), and in addition, less than $10 \%$ of mothers with raised MSAFP and a normal singleton fetus, delivery a low birthweight infant $[1,7]$; in our study $7 \%$ of singleton pregnancies with raised MSAFP resulted in a low birthweight infant. Thus, increasing antenatal care in pregnancies with raised MSAFP levels would not likely be effective in reducing the overall incidence of fetal growth retardation but might confer other benefits and this association needs further study.
It seems reasonable thidt raised MSAFP levels might be associated with spontaneous abortion as found here since various factors which may adversely affect the pregnancy sufficiently to cause spontaneous abortion may be present at the time of the test. Stillbirths are more often the result of factors occurring later in pregnancy and are unlikely to be detected by MSAFP testing in the second trimester. In our sample of stillbirths, the distribution of MSAFP levels is consistent with that in the general pregnant population.

\section{Summary}

Maternal serum $\alpha$ fetoprotein (MSAFP) measurement between 16 and 21 weeks gestation is used to define a group of women with an increased risk of fetal abnormality, particularly open neural tube defect. The test is strongly gestation dependent and women with high MSAFP levels require sonar scan examination to define gestation, exclude twins and examine the fetus for obvious malformation or death. It has been reported that women with no primary cause for raised MSAFP have an increased incidence of low birth weight babies. Conflicting reports have separately ascribed these to premature delivery and to intra-uterine growth retardation.

We have studied the relationship between MSAFP and low birth weight infants with respect to both prematurity and retarded fetal growth. MSAFP values were expressed as multiples of the appropriate weekly median (MOM) values relating to normal pregnancies with normal outcomes at term. For our normal population an MSAFP value of $2 \mathrm{MOM}$ is the $95 \%$ centile, i.e. $5 \%$ of normal outcome pregnancies of sure gestation will have MSAFP values in the second trimester which are at or above 2 MOM.

Information was available on 389 women whose infants were liveborn singletons weighing $2.5 \mathrm{~kg}$ or less. 33
$(8.5 \%)$ of these women had MSAFP $>2$ MOM $(p<0.005)$ and of the 145 women whose babies weighed less than $2 \mathrm{~kg}, 17(11.7 \%)$ had MSAFP at this level $(\mathrm{p}<0.001)$ Tab.I).

There was little evidence of an association between raised MSAFP and premature delivery but a significant number of women with raised MSAFP had low birthweight infants after 37 weeks gestation $(p<0.005)$ (Tab. II).

When the data were analysed in relation to standard birthweight centiles for gestation, sex and parity, (Tab. III), 19 out of 203 women $(9.4 \%)$ with light-for-dates babies had raised MSAFP compared with 6 out of $122(4.9 \%)$ women with appropriate-for-dates babies $(p<0.005)$ (Tab. III).

Raised MSAFP was also found more frequently $(p<0.002)$ in pregnancies ending in spontaneous abortions than in the general population.

Thus, in the absence of fetal abnormality, elevated MSAFP in the second trimester may indicate a fetus at increased risk of spontaneous abortion or intra-uterine growth retardation.

Keywords: Birthweight, intra uterine growth retardation, maternal serum AFP, small for dates.

\section{Zusammenfassung}

Alpha-Fetoproteinspiegel im mütterlichen Serum bei Einlingsschwangerschaften mit niedrigem Geburtsgewicht Zur Erfassung eines erhöhten Risikos von fetalen Mißbildungen, speziell Neuralrohrdefekten, wird zwischen der 16. und 21. Schwangerschaftswoche das Alpha-Fetoprotein im mütterlichen Serum (MSAFP) bestimmt. Die Konzentration korreliert eng mit dem Gestationsalter. Bei Frauen mit erhöhtem AFP-Spiegel sollte eine Ultraschalluntersuchung durchgeführt werden, um das Schwangerschaftsalter zu bestimmen und um Zwillinge sowie fetale Mißbildungen oder. einen abgestorbenen. Feten auszu- schließen. Es wurde berichtet, daß Frauen mit erhöhtem AFP gehäuft Kinder mit niedrigem Geburtsgewicht gebären. $\mathrm{Ob}$ dabei eine Frühgeburt oder eine intrauterine Wachstumsretardierung zugrunde liegt, wird widersprüchlich diskutiert.

Wir untersuchten den Zusammenhang zwischen MSAFP und niedrigem Geburtsgewicht sowohl unter dem Aspekt der Frühgeburtlichkeit als auch der intrauterinen Wachstumsretardierung. Die MSAFP-Werte wurden als Multiple der angemessenen, wöchentlichen Mittelwerte (MOM), die für komplikationslose Schwangerschaften mit Gebur- 
ten am Termin aufgestellt worden waren, ausgedrückt. Für unsere Normalbevölkerung liegt ein MSAFP-Wert von 2 MOM auf der 95. Perzentile, d.h., daß bei normalem Schwangerschaftsverlauf und sicherem Gestationsalter $5 \%$ der Schwangeren im 2. Trimenon MSAFP-Werte bei oder oberhalb von 2 MOM haben.

Uns lagen Werte von 389 Frauen vor, deren lebendgeborene Kinder ein Geburtsgewicht von $2,5 \mathrm{~kg}$ und weniger hatten. 33 dieser Frauen $(8,5 \%)$ hatten MOMWerte $\geqslant 2$ MOM $(p<0,005)$. Von den 145 Frauen, deren Kinder weniger als $2 \mathrm{~kg}$ wogen, hatten $17(11,7 \%)$ MSAFP-Werte $\geqslant 2$ MOM $(p<0,001$, Tab. I). Es gab wenig Hinweise für einen Zusammenhang zwischen erhöhtem MSAFP und einer Frühgeburt. Die Anzahl von Frauen mit hohem AFP und Kindern mit niedrigem Geburtsgewicht nach der 37. Schwangerschaftswoche war dagegen signifikant erhöht ( $p<0,005$, Tab. II).
Nach Analyse der Daten unter Verwendung von Gewichtsperzentilen, in denen das Gestationsalter, das Geschlecht und die Parität berücksichtigt werden, ergab sich folgendes: 19 von 203 Frauen $(9,4 \%)$ mit untergewichtigen Kindern hatten ein erhöhtes MSAFP, dagegen nur 6 von 122 Frauen $(4,9 \%)$, deren Kinder normalgewichtig waren. Dieser Unterschied ist signifikant ( $p<0.005$, Tab. III).

Bei Schwangerschaften, die mit einem Spontanabort endeten, wurden auch öfter erhöhte MSAFP-Werte gefunden als in normalen Schwangerschaften ( $p<0,002)$.

Liegen keine fetalen Mißbildungen vor, kann ein angestiegenes MSAFP im 2. Trimenon Ausdruck eines erhöhten Risikos für einen Spontanabort oder einer intrauterinen Wachstumsretardierung sein.

Schlüsselwörter: AFP im mütterlichen Serum, Geburtsgewicht, intrauterine Wachstumsretardierung, Small-for-dateBabies.

\section{Résumé}

Taux d'alpha-fœtoprotéines sériques maternels au cours des grossesses avec enfants de faible poids de naissance L'estimation de l' $\alpha \mathrm{FP}$ sérique maternelle (MS $\alpha \mathrm{FP}$ ) entre 16 et 21 semaines de gestation est utilisée pour la définition d'un groupe de femmes enceintes à risque d'avoir des enfants porteurs de graves malformations congénitales et particulièrement de défaut de fermeture spinale. Le dosage de l'MS $\alpha \mathrm{FP}$ a une corrélation très significative avec l'âge gestationnel et une femme enceinte présentant une valeur élevée nécessite une échographie pour confirmer l'âge gestationnel, pour éliminer une grossesse gémellaire et pour rechercher des malformations fœtales ou les morts intra-utérines. On a rapporté qu'il existe une augmentation significative des enfants de faible poids de naissance chez les femmes ayant une élévation de l'MS $\alpha F P$ sans cause. Des publications contradictoires ont attribué cette augmentation aux accouchements prématurés ou au retard de croissance intra-utérin (RCIU).

Nous avons tenté d'apporté un peu de lumière sur cette question en mesurant les concentrations de l'MS $\alpha \mathrm{FP}$ et en les mettant en rapport avec l'incidence des accouchements prématurés et du retard de croissance intra-utérin chez les enfants de faible poids de naissance. Les valeurs de l'MS $\alpha \mathrm{FP}$ ont été calculées comme les multiples des valeurs moyennes (VM), par rapport à l'âge gestationnel, obtenues au cours des grossesses normales ayant abouti à un nouveau-né unique, de poids de naissance normal, à terme et en bonne santé. Dans notre population normale, une valeur de l'MS $\alpha \mathrm{FP}=2 \mathrm{VM}$ est au percentile $95: 5 \%$ des parturientes à terme avec des grossesses normales et ayant accouché d'enfants normaux ont des valeurs de $l^{\prime} \mathrm{MS} \alpha \mathrm{FP}$ pendant le deuxième trimestre $\geqslant 2 \mathrm{VM}$.

Les auteurs étudient 389 mères ayant accouché d'enfants uniques avec un poids de naissance inférieur à $2,5 \mathrm{~kg}$. $\mathrm{La}$ concentration d' $\alpha$ FP était $\geqslant 2 \mathrm{VM}$ dans le sang de 33 $(8,5 \%)$ de ces femmes enceintes entre 16 et 20 semaines de gestation $(p<0,005)$ et $17(11,7 \%)$ des 145 mères ayant accouché d'enfants avec un poids inférieur à $2 \mathrm{~kg}$ $(p<0,001)$ (Tab.I).

Il n'a pas été mis en évidence de corrélation significative entre l'MS $\alpha \mathrm{FP}$ élevée et laccouchement prématuré, mais un nombre significatif de femmes enceintes dont les valeurs de 1'MS $\alpha \mathrm{FP}$ étaient élevées ont accouché d'enfants de faible poids de naissance après 37 semaines de gestation ( $p<0,005)$ (Tab. II).

Quand on tient compte des répartitions par rapport aux courbes de percentiles du poids de naissance pour l'âge gestationnel, pour le sexe et pour la parité, 19 des 203 mères ayant des enfants hypotrophiques avaient des valeurs d'MS $\alpha \mathrm{FP}$ élevées $(9,4 \%)$ et seulement 6 des 122 mères ayant des enfants correspondant à l'âge gestationnel (Tab. III).

Egalement, nous avons trouvé des valeurs d'MS $\alpha \mathrm{FP}$ élevées plus fréquemment $(\mathrm{p}<0,002)$ au cours des grossesses aboutissant à un avortement spontané.

Ainsi, en l'absence de malformation congénitale, l' $\alpha \mathrm{FP}$ sérique maternel (MS $\alpha \mathrm{FP})$ élevée au cours du 2ème trimestre s'accompagne d'un risque de fausse-couche ou de retard de croissance intra-utérin (RCIU).

Mots-clés: $\quad \alpha$ FP sérique maternelle, hypotrophie, poids de naissance, retard de croissance intra-u térin.

\section{Bibliography}

[1] BROCK, D. J. H., L. BARRON, P. JELEN et al.: Mater: nal serum alpha-fetoprotein measurements as an early indicator of low birthweight. Lancet 2 (1977) 267

[2] BROCK, D. J. H., L. BARRON, M. WATT et al.: Maternal plasma $\alpha$-fetoprotein and low birthweight: a prospective study throughout pregnancy. Br. J. Obstet. Gynaec. 89 (1981) 348

[3] MACRI, J. N., R. R. WEISS, B. LIBSTER, et al.: Maternal serum- $\alpha$-fetoprotein and low birth-weight. Lancet 1 (1978), 660 
[4] PURDIE, D. W., J. L. YOUNG, K. A. GUTHRIE, et al.: Fetal growth achievement and elevated maternal serum $\alpha$-fetoprotein. Br. J. Obstet. Gynaec. 90 (1983) 433

[5] SMITH, M. L.: Raised maternal serum alpha fetoprotein levels and low birthweight babies. Br. J. Obstet. Gynaec. 87 (1980) 1099

[6] THOMSON, A. N., W. A. BILlEWICZ, F.E.HYTTEN: The assessment of fetal growth. J.Obstet.Gynaec. Brit. Cwlth. 75 (1968) 903

[7]WALD, N. J., H. S. CUCKLE, G. M. STIRRAT, et al.: Maternal serum alpha-fetoprotein and low birthweight. Lancet 2 (1977) 268
[8] WALD, N. J., H. S. CUCKLE, J. BOREHAM, et al.: Maternal serum $\alpha$-fetoprotein and low birth weight in relation to gestational age. Br. J. Obstet. Gynaec. 89 (1982) 216

Received January 7, 1984. Accepted March 19, 1984.

C. M. Buckland Department of Child Health University of Aberdeen Foresterhill

GB-Aberdeen, AB9 2ZD

Great Britain 